\title{
Humanity-Based Language Learning
}

\author{
Rosida Tiurma Manurung ${ }^{1}$, Evany Victoriana ${ }^{2}$, Alfredo Ezra Amadeus ${ }^{3}$ \\ Universitas Kristen Maranatha \\ rosidatm@gmail.com \\ evany.victoriana@psy.maranatha.edu \\ edoezdeus@gmail.com
}

Received: 04 March 2021; Revised: 26 April 2021; Accepted: 28 April 2021

DOI: http://dx.doi.org/10.37905/aksara.7.2.763-770 .2021

\begin{abstract}
This research is about language learning with a human perspective. The purpose of this paper is to find out how students respond and respond to language learning with a humanitarian perspective among active students. This research is a research with a qualitative descriptive analysis approach, namely a technique that analyzes, describes, and summarizes various situations and conditions. The data collection technique in this study was using a questionnaire aimed at active students with ages between 18-25 years, in the questionnaire presented statements that needed to be answered by respondents in a factual and honest manner. Based on the results of research on language learning with a humanitarian perspective, it was found that the majority of respondents used good and correct Indonesian with human values because it grew from an attitude of caring for others and an attitude of helping. This study also found that students have respected the state language as a language of instruction in the world of education, students agree that human values can be developed to shape one's character so that it can be implemented in language learning and there is concern with Indonesian language education for the wider community with values. human values.
\end{abstract}

\section{Keywords}

language learning, humanitarian perspective, Indonesian language, human values

\section{INTRODUCTION}

Language means communicating using language media. Language must be easily understood and understood by all people in a country. According to Ferdinand de Saussure, language is a social fact, that is, language is used as a tool to communicate. Language is a social fact because in every language there is a collective product, an artifact created by its speakers (in Coulmas, 2006: 3). Indonesian is the unified language of the Indonesian nation as stated in the Youth Oath of October 28, 1928. Indonesian has multiple functions, being the language of unity, the language of the state, the official language, and the language of communication between individuals, as well as the language of association. Although there are still many people who use Indonesian as a second language, nowadays more and more people are concerned about using Indonesian as their first language. 
Language learning is the ability to use language in all its functions, namely a means of communication, a means of thinking, a means of unity, and a means of culture. Language learning is directed at improving one's ability to communicate using Indonesian properly and correctly. Language learning with a humanitarian perspective refers to the view of language learning with the theme of empathy and compassion through an attitude of concern with Indonesian language education with human values. Humanity is an inner and outer glory with a purity of heart towards human etiquette. According to the National Center for Vocational Education Research Ltd, there are three meanings of learning materials, namely: 1) are information, tools and texts needed by teachers/instructors for planning and reviewing learning implementation; 2) all forms of materials used to assist teachers/instructors in teaching and learning activities in the classroom; 3) a set of learning substances that are arranged systematically, showing a complete figure of the competencies that will be mastered by students in the learning process. The feasibility of literature as a learning material in junior high schools is reflected in the use of literature, namely to (1) know various good human characters, (2) interpret and explain various characters in life, (3) show examples of character behavior in everyday life. , (4) understand the good side of character behavior, (5) understand the bad effects of humans because they do not carry out good character, and (6) carry out character behavior in everyday life (Sunarti (2005:6-7). as a learning medium in the digital era must be able to present learning in an interesting and effective manner.Therefore, a teacher must master various learning methods in order to foster psychological effects and different characters and must be precise in choosing teaching materials to be used for language learning. According Nurgiyantoro (1995), the problems inherent in language teaching materials can be a matter of social relationships: friendship and loyalty; family relationships: parental love for children, brother for younger siblings, mutual love for fellow human beings, developing an attitude of tolerance, fond of doing humanitarian activities. Based on the above understanding, problems based on humanity can fill the content of language learning. The purpose of this study is to find out how students respond and respond to language learning with a humanitarian perspective and use it as an evaluation material.

\section{METHOD}

The source of research data on the problem that has been formulated is by collecting data online through filling out a questionnaire (google form). The research used is a qualitative descriptive analysis approach. According to I Made Wirartha (2006:155), qualitative descriptive analysis is a technique that analyzes, describes, and summarizes various situations and conditions from various data collected in the form of interviews or observations about the problems studied in the field. Language learning is analyzed from a humanitarian perspective based on data obtained from the results of research in the field. The method used is descriptive qualitative method, which is an appropriate method to analyze language learning in a humanitarian perspective based on facts among active students aged 18-25 years. The survey method is the method we use. The data collection technique used is a questionnaire (questionnaire) which is explained descriptively according 
to the facts from the data collected in this study. Questionnaires are data collection techniques that can be given directly, by post, or the internet by giving a set of written questions to respondents to answer (Sugiyono 2008:142).

\section{RESULTS AND DISCUSSION}

\section{Result}

For the question "using structured, good, and correct Indonesian in writing reports means that we have respected Indonesian as the language of instruction in the world of education" the following data is generated.

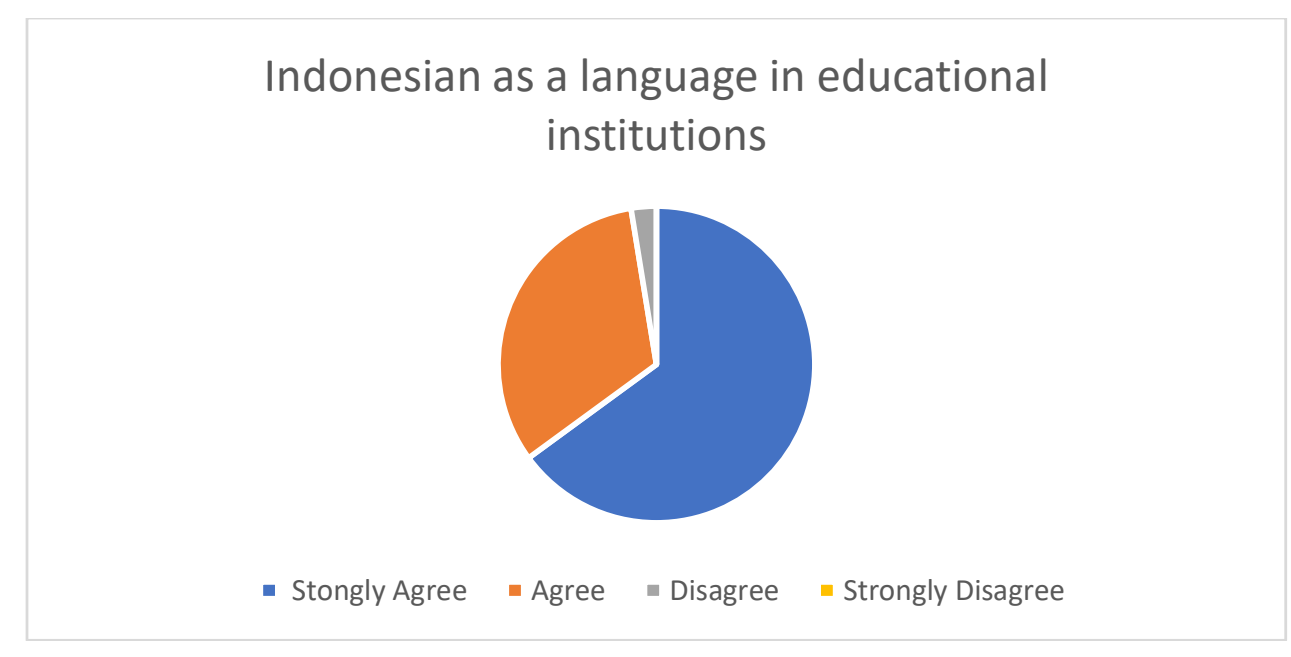

In the question items of the questionnaire "are currently students active in humanitarian-based activities including language learning with the theme of empathy and compassion", the following answers were obtained.



The results for the question "whether language learning can be used as a vehicle to educate students on the importance of implementing human values in everyday 
life" are shown in the diagram below.

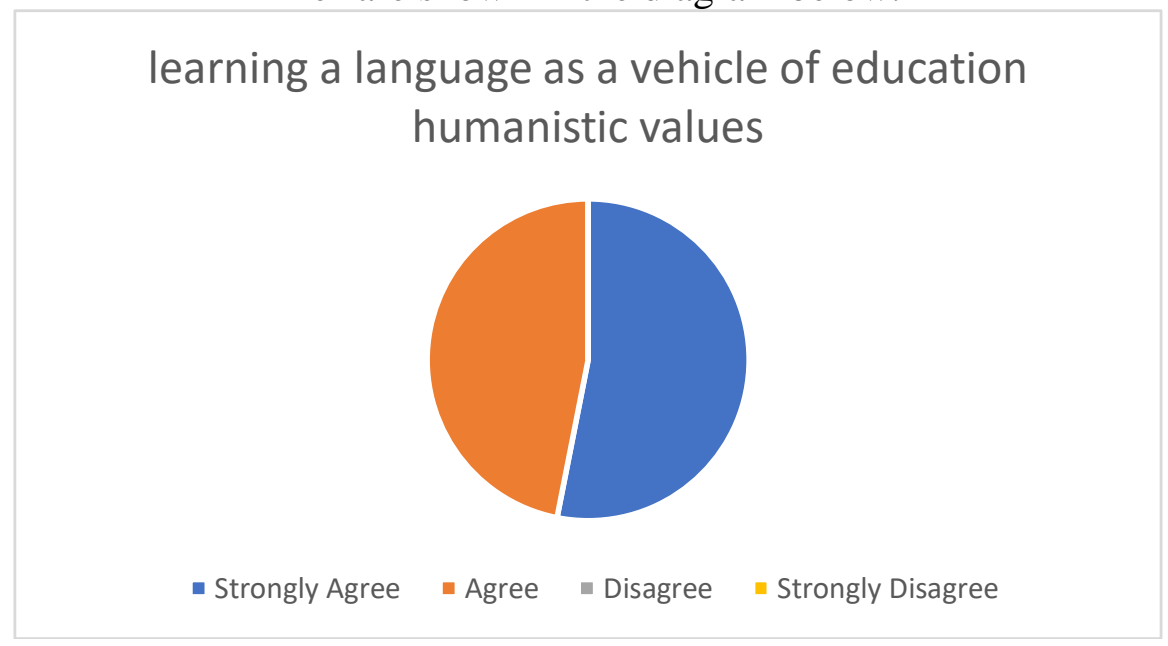

For the question "do students need to contribute to writing literacy on the theme of humanity", the results of data processing are shown in the diagram below.

writing literacy with the theme of humanity

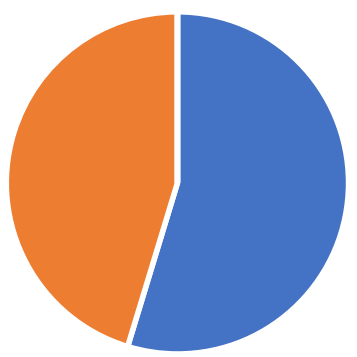

- Strongly agree $\quad$ Agree $\quad$ Disagree $=$ Strongly Disagree

Respondents' responses to the question "do you agree that human values can be integrated in language learning' are shown in the diagram below. 


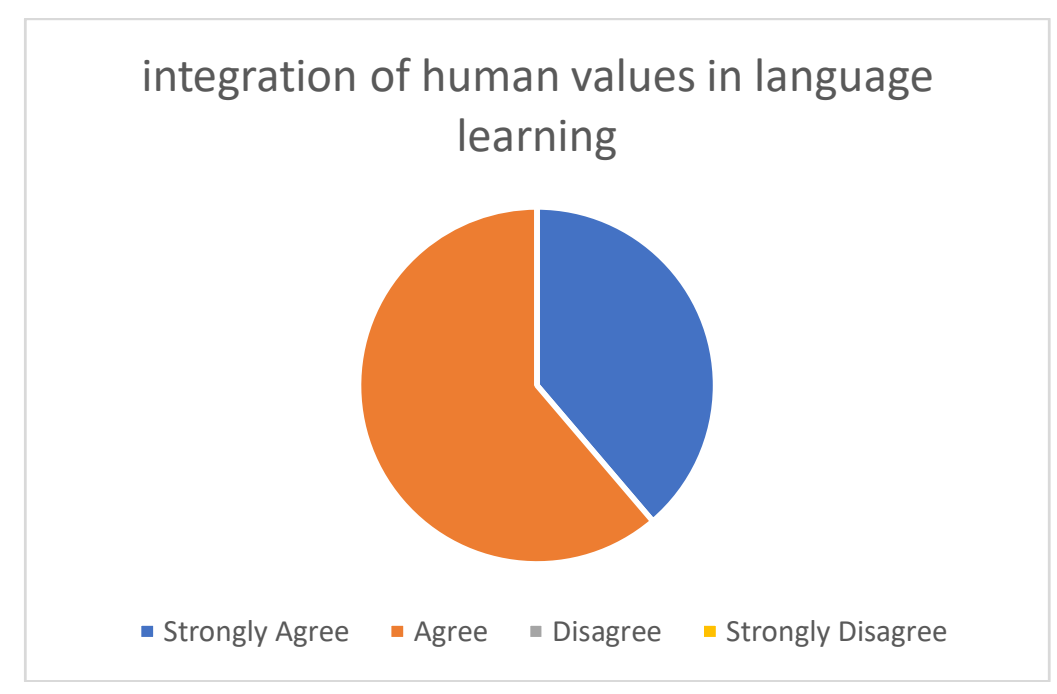

Language learning which concerns how to build positive communication in a humanitarian perspective is very important to be used as teaching material, especially for the millennial generation. Respondents' responses can be seen from the following diagram.

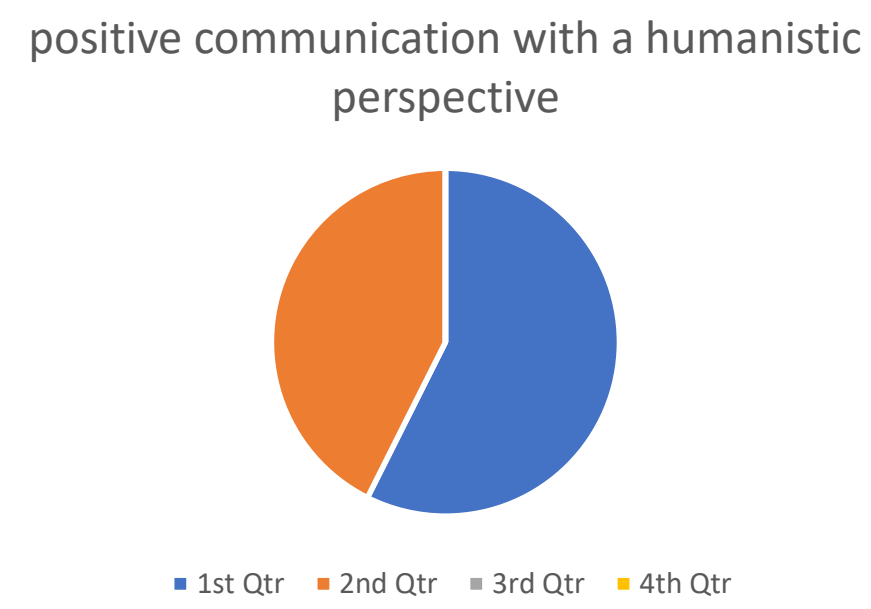

Based on the results of research that has been conducted on 64 respondents, the majority of respondents use Indonesian properly and correctly in writing reports and course assignments as much as $65.6 \%$, which means that students have respected the state language as the language of instruction in the world of education. From the results of this study, it was also found that the average respondent as much as $59.4 \%$ agreed, about human values, namely empathy and compassion can be developed to shape one's character so that it can be integrated in language learning. A total of $54.7 \%$ respondents strongly agree that at this time, language learning can be used as a vehicle to educate students the importance of implementing human values in everyday life. According to the results of the study that students' caring attitudes towards humanity can be disseminated through information or education in good and correct Indonesian, the average respondent strongly agrees that as much 
as $53.1 \%$. On average, $60.9 \%$ of respondents strongly agree if it is integrated in language learning. In addition, by building positive verbal communication, human values can be improved, especially among the millennial generation, the average respondent is $57.8 \%$.

\section{Discussion}

From the results of this study, it can be classified some of the benefits of language learning with a humanitarian perspective, namely as follows that form a person's character. Character is a pattern of a person's behavior, people with good character have an understanding of goodness, like goodness, and do good. By shaping one's character, the greater the chance of the individual being a good person. The increasing concern for language defense is the impact of using good and correct language in student writing. In this case, it shows that caring and loyalty to a language is to be maintained and to bind a sense of brotherhood, especially Indonesian in the midst of other languages that are increasingly popular. Students play an active role in humanitarian activities, such as providing assistance to disaster victims, both in disaster areas and in conflict areas. The involvement of students in building positive verbal communication plays a very important role in increasing mental resilience, especially during the pandemic. Positive verbal communication can be easily recognized because it communicates through words and verbal symbols in its use of language.

\section{CONCLUSION}

Based on the results of research and discussion, it can be concluded that the majority of respondents use good and correct Indonesian with human values because it grows from an attitude of caring for others and an attitude of helping. From language learning with a humanitarian perspective, the benefits are classified as follows:

1. Form a person's character.

2. Increase awareness of language defense.

3. Be active in humanitarian activities

4. Build positive verbal communication.

Based on the results of the study, it was also found that respondents still did not agree with playing an active role in humanitarian-based activities and felt concerned about Indonesian language education for the wider community with human values. And human values can be developed to shape one's character so that it can be implemented in learning. The benefit of this research is that students' responses and responses to language learning with a humanitarian perspective can be known and become material for improvement and evaluation for us so that we can be even better and optimal in providing benefits from future research. 


\section{REFERENCES}

Burhan, Nurgiyantoro. 1995. TeoriPengkajianFiksi. Yogyakarta : Gadjah Mada University Press.

Chaedar, Al Wasilah. 2006. "PengajaranBerbasis Sastra". Diaksesdarihttp://www.pikiran-rakyat.com pada 11 September 2020.

Goleman, Daniel. 1997. Emotional Intelligence KecerdasanEmosionalMengapa EI LebihPentingdaripada IQ (diterjemahkan T. Hermaya). Jakarta: Gramedia.

Hari, C. S. (2016). "Sastra Digital Dan Penyebaran Sastra Indonesia Melalui Industri Kreatif." Diunduhdari http://www.mantagibaru.com/2016/01/sastradigital-dan-penyebaran-sastra.html.

Krismawati. 2015. "Penggalian Nilai-Nilai KemanusiaandalamPembelajaranKritiksastraberbasisPedagogiIgnasian”. Seminar Nasional Sastra, Pendidikan Karakter dan IndustriKreatifSurakarta, 31 Maret 2015.

Kusmarwanti. 2012. "MenumbuhkanKarakter Anak MelaluiPembelajaran Sastra Di Sekolah Dasar". Makalah Seminar Nasional, Universitas Negeri Yogyakarta).

Moleong, Lexy. 2014. MetodePenelitianKualitatif, EdisiRevisi. PT RemajaRosdakarya

Sugiyono. 2014. Metode Penelitian Kuantitatif Kualitatif Dan R\&D. Bandung: CV Alfabeta.

Sunarti. 2005. MenggaliKekuatanCerita. Jakarta : Elex Media KomputindoKelompok Gramedia.

Widiastono, Tony D. 2002. "Hati-HatiMemilihBukuBacaan Anak-Anak" dalam 'Sekolah' Alternatifuntuk Anak (SintaRatnawati ed.). Jakarta: Penerbit Buku Kompas.. 
AKSARA: JurnalIImu Pendidikan Nonformal

P-ISSN $\underline{2407-8018}$ E-ISSN $\underline{2721-7310}$ DOI prefix $\underline{10.37905}$

Volume 07 (02) May 2021

http://ejurnal.pps.ung.ac.id/index.php/Aksara

770 AKSARA: Jurnal Ilmu Pendidikan Nonformal 